\title{
原著
}

\section{当院皮膚科を紹介受診した長期ステロイド治療犬に おける副作用と臨床検査成績の関係}

\author{
柴田久美子* 永田雅彦
}

ASC どうぶつ皮膚病センター

\begin{abstract}
要 約
当院皮膚科を紹介受診したステロイド長期治療犬40例を調查したところ，27例で副作 用として多飲多尿，食欲増進，あえぎ呼吸，腹囲膨満，骨格筋萎縮などの全身症状，あ るいは皮虐石灰沈着症，脱毛，皮膚の菲薄化，血管の明瞭化，紫斑，面皰などの皮疹 が観察された。副作用発症犬と非発症犬の臨床検査成績を比較したところ, 有意差を 統計学的に認めたのはALPとALTであり，発症犬ではそれぞれの増加が74.1\%, 55.6

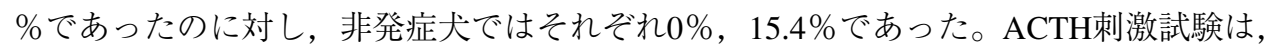
両者とも副腎予備能の低下が高率に認められ，発症犬は $77.8 \%$, 非発症犬は $69.2 \%$ で あった。したがって医原性クッシングの評価を ACTH 刺激試験単独で行うことはでき ず，症状の観察とALT，ALP測定が不可欠であることが明らかにされた。 キーワード：ALT, ALP, ACTH 刺激試験，ステロイド治療
\end{abstract}

\section{緒 言}

生体内に打いてステロイドホルモンは正常な代謝機 能に不可欠な内因性物質である。臨床では抗炎症作用 を期待した治療としてステロイド投与が行われる。ス テロイドは効果的な治療薬であると同時に副作用の発 現が懸念され，特に長期投与では医原性クッシング症 候群に対する症状の観察や血液学的および副腎の機能 的なモニターが推奨されている。今回われわれは，皮 膚科を紹介受診しステロイドで長期加療されていた症 例を対象として，医原性クッシング症候群を示す症状

*連絡先：柴田久美子(ASC どうぶつ皮膚病センター) 干 180-0012 東京都調布市深大寺東町 1-3-2 TEL 0424-80-9342 FAX 0424-41-6095

E-mail shibata@gc4.so-net.ne.jp
の有無と血液学的異常および副腎予備能の関係を検討 した。

\section{材料と方法}

平成 6 年 10 月から平成 14 年 8 月の約 8 年間に皮膚病 を主訴に当施設を紹介受診した犬を対象とし，ステロ イドの内服, 皮下注射, 外用剂で最低 1 力月以上加療 されていた犬を本試験に供した。ステロイドによる全 身症状として多飲多尿, 食欲増進, あえき呼吸, 腹囲 膨満，骨格筋萎縮，皮疹として脱毛，面皰，皮膚石灰 沈着症，皮膚の菲薄化，血管の明瞭化，紫斑に注目し， いずれかの症状が観察された犬を発症犬，全く認めな かった犬を非発症犬とした。

血液学的評価では, 血液検査, 血液化学検査を実施 
し，発症犬および非発症犬における異常值の発現率を 検討した。ステロイド投与により生じる特徵的な所見 として, 血液検査では総白血球増加, 好中球増加, リ ンパ球減少, 好酸球減少, 血液化学検査ではALP増加, ALT増加, BUN減少, コレステロール増加, 高血糖に 注目した。血液検査はQBC Vet Autoreader(IDEXX) で 行い, 白血球百分比は血液塗抹標本を作成し算出し た。血液化学検查は一部を除きVet Test（IDEXX）で 行った。血液検查の正常值は総白血球 $6,000 \sim 17,000 /$ $\mu \mathrm{l}$, 好中球 $3,000 \sim 11,500 / \mu 1$, リンパ球 $1,000 \sim 4,800$ / $\mu \mathrm{l}$, 好酸球 $100 \sim 1,250 / \mu \mathrm{l}$, 血液化学検査はVet Testの 参考値を用いALP $23 \sim 212 \mathrm{U} / \mathrm{L}$ ，ALT $10 \sim 100 \mathrm{U} / \mathrm{L}$, BUN $7.0 \sim 27.0 \mathrm{mg} / \mathrm{dl}, \quad$ コレステロール $110.0 \sim 320.0$ $\mathrm{mg} / \mathrm{dl}, \quad$ グルコース $77.0 \sim 125.0 \mathrm{mg} / \mathrm{dl}$ とし, 範囲外の 数值を異常とした ${ }^{8)}$ 。

副腎皮質機能はACTH刺激試験（以下ACTH-ST）に より評価した。ACTH-ST は, 塩酸テトラコサクチド （コートロシン注：第一製薬株式会社） $0.25 \mathrm{mg} / \mathrm{head}$ 筋肉内注射し, 刺激前揖よび刺激 1 時間後の血漿コル チゾール值を測定した。ACTH-ST で刺激後のコルチ ゾール值 $6 \mu \mathrm{g} / \mathrm{dl}$ 未満を副腎予備能の低下とした3)。

\section{結 果}

供試犬は40例で, 副作用発症犬は27例であった。全 身症状として多飲多尿が 19 例 (70.4\%), 食欲増進が 14 例 $(51.9 \%)$, 腹囲膨満が 8 例 $(29.6 \%)$, あえざ呼 吸と骨格筋萎縮が 6 例 $(22.2 \%)$, 皮疹として脱毛が 15 例 (55.6\%), 面皰が9例 (33.3\%), 皮膚石灰沈着症が 8 例 $(29.6 \%)$, 皮膚の菲薄化が 6 例 $(22.2 \%)$, 血管の 明瞭化が4例 $(14.8 \%)$ ，紫斑が2例 $(7.4 \%) に$ にら た。発症犬の内訳は，平均年齢が 6.6 歳齢 $(7$ 月月 12 歳齢), 性別は雄 18 例, 雌9例, 犬種はシー・ズー6例, パグ，マルチーズ各3例，ブルドッグ，雑種犬各2例， プードル, ポメラニアン, コッカー・スパニエル，ゴー ルデン・レトリバー，ミニチュア・ピンシャー, ウエ スト・ハイランド・ホワイトテリア，コリー，秋田犬， 柴犬, ドーベルマン・ピンシャー, ビーグル各 1 例で あった。な抄発症犬は 13 例で，年齢が平均 5.3 歳齢 (2〜13 歳齢), 性別は雄 4 例, 雌 9 例, 犬種はフレン チブルドック，パグが各 2 例, ドーベルマン・ピン シャー，ポリッシュ・ローランド・シープドッグ，ミ
ニチュア・ピンシャー，ヨークシャー・テリア，シー・ ズー,コーギー，柴犬，ミニチュア・ダックスフンド， 雑種犬が各 1 例であった。

血液検查成績の詳細をTable 1に示した。発症犬では リンパ球減少が $58.3 \%$ (14/24例) と半数以上にみられ, ついで好中球増加が $41.7 \%$ (10/24例), 好酸球減少が 29.2\%（7/24例）, 総白血球増加が $22.2 \%$ (6/27例) で あった。一方非発症犬もリンパ球減少が $38.5 \%$ （5/13 例）と最も多くみられ, 次いで総白血球増加および好 中球増加が $23.1 \%$ (3/13例), 好酸球減少が $15.4 \%$ (2/ 13）であった。総白血球数以外は発症犬で異常值を認 めやすかったが統計学的有意差はなかった（Fig. 1)。

血液化学検査では, 発症犬でALP増加が74.1\% (20/ 27 例）と最も多く, 次いでALT 増加が 55.6\%（15/27 例）と半数以上の症例で認められ, さらにBUN減少, 高血糖が $22.2 \%$ (6/27例), 高コレステロール血症が 14.8\%（4/27 例）であった。一方非発症犬では, 発症 犬と対照的にALP 増加は全くみられなかった（0/13 例)。他の項目は高血糖が $23.1 \%$ (3/13例) と発症犬と ほぼ同様であったが, ALT増加は15.4\%(2/13例), BUN 減少は7.7\% (1/13例)，コレステロール増加はなく（0/ 13 例）と発症犬に比較し異常值の発現率が低かった

(Table 2, Fig. 2)。

ACTH刺激試験による副腎予備能の抑制は, 発症犬 で $77.8 \%$ (21/27 例)，非発症犬で $69.2 \%$ (9/13 例）と いずれも高率に認められた（Table 3)。

\section{考 察}

ステロイドで1カ月以上治療された犬では発症犬お よび非発症犬ともに約 $70 \%$ の症例で副腎予備能の低下 がみられた。生体内ではグルココルチコイドが副腎か ら分泌され，フィードバック作用により視床下部掞よ び下垂体を介して調節されている1)。外因性ステロイ ドも同様にフィードバック作用を有し，プレドニゾン $0.22 \mathrm{mg} / \mathrm{kg}, 0.55 \mathrm{mg} / \mathrm{kg} \mathrm{SIDで7日以内,} 1.1 \mathrm{mg} / \mathrm{kg}$ EOD で21日以内に副腎抑制が生じると報告されている ${ }^{2)}$ したがって ACTH-STによる副腎予備能の低下は必ず しも病的状態といえず，内外の過剩ステロイドに対す る生体の恒常性に関係していることが明らかにされ た。自験例をみても, 軽微ながら副婜予備能を有して いる症例では, 飼い主の判断でステロイドが休薬され 
Table 1. Hematological findings in dogs on glucocorticoid therapy*

\begin{tabular}{|c|c|c|c|c|c|c|c|c|c|}
\hline \multicolumn{5}{|c|}{ Dogs with side effects } & \multicolumn{5}{|c|}{ Dogs without side effects } \\
\hline Case & WBC & Seg & Lym & Eos & Case & WBC & Seg & Lym & Eos \\
\hline 1 & 13300 & 11305 & 931 & 266 & 1 & 9200 & 8280 & 644 & 0 \\
\hline 2 & 18800 & 16168 & 752 & 0 & 2 & 13800 & 11454 & 690 & 828 \\
\hline 3 & 19600 & 9800 & 1370 & 780 & 3 & 11800 & 9676 & 1652 & 177 \\
\hline 4 & 12400 & 6696 & 2604 & 1116 & 4 & 5500 & 3960 & 1100 & 110 \\
\hline 5 & 9100 & 8535 & 73 & 65 & 5 & 11500 & 10810 & 230 & 0 \\
\hline 6 & 10800 & 7992 & 540 & 648 & 6 & 10900 & 8284 & 872 & 763 \\
\hline 7 & 11000 & 8140 & 990 & 440 & 7 & 17100 & 12312 & 2394 & 1197 \\
\hline 8 & 15300 & 11628 & 2295 & 0 & 8 & 19000 & 9880 & 7220 & 190 \\
\hline 9 & 30200 & 25972 & 604 & 2718 & 9 & 14400 & 10656 & 1728 & 432 \\
\hline 10 & 8800 & 5632 & 2288 & 440 & 10 & 11000 & 7260 & 1650 & 550 \\
\hline 11 & 11000 & 8910 & 550 & 880 & 11 & 5900 & 2950 & 2419 & 177 \\
\hline 12 & 5900 & 4071 & 1593 & 0 & 12 & 16100 & 14651 & 644 & 161 \\
\hline 13 & 24100 & 18798 & 482 & 2410 & 13 & 19700 & 16154 & 1576 & 193 \\
\hline 14 & 20000 & 18000 & 1200 & 0 & & & & & \\
\hline 15 & 16500 & 15510 & 495 & 0 & & & & & \\
\hline 16 & 15300 & 12546 & 765 & 0 & & & & & \\
\hline 17 & 10900 & 7521 & 1635 & 545 & & & & & \\
\hline 18 & 10200 & 8568 & 612 & 306 & & & & & \\
\hline 19 & 16000 & 14240 & 640 & 640 & & & & & \\
\hline 20 & 10800 & 9288 & 864 & 108 & & & & & \\
\hline 21 & 6000 & 4800 & 1020 & 60 & & & & & \\
\hline 22 & 11900 & 8806 & 1547 & 1428 & & & & & \\
\hline 23 & 15600 & & & & & & & & \\
\hline 24 & 15400 & & & & & & & & \\
\hline 25 & 9900 & & & & & & & & \\
\hline 26 & 15800 & 13114 & 1896 & 158 & & & & & \\
\hline 27 & 17270 & 14248 & 518 & 432 & & & & & \\
\hline
\end{tabular}

*WBC: white blood cell, Seg: segmented neutrophil, Lym: lymphocyte, Eos: eosinophil $(/ \mu \mathrm{l})$.

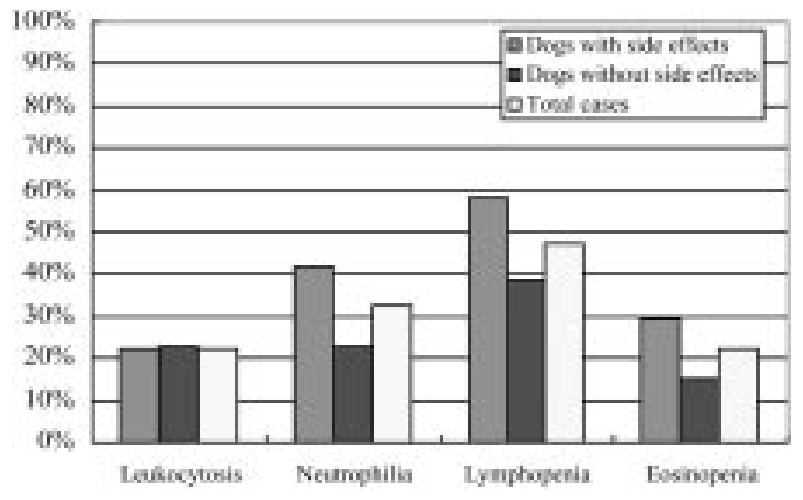

Fig. 1. Incidence of hematological abnormalities in dog treated with glucocorticoid.

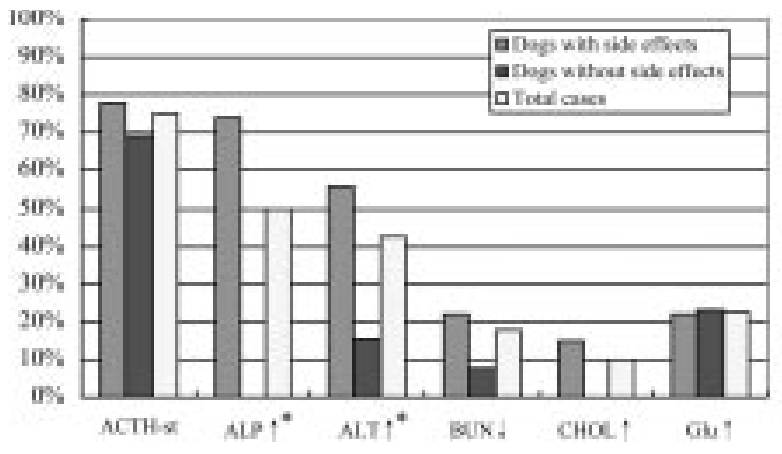

Fig. 2. Incidence of biochemical abnormalities in dog treated with glucocorticoid. *Statistically significant difference between dogs with and without side effects (Chi-square test, $\mathrm{p}<0.05$ ). 
Table 2. Biochemical findings in dogs on glucocorticoid therapy*

\begin{tabular}{|c|c|c|c|c|c|c|c|c|c|c|c|}
\hline \multicolumn{6}{|c|}{ Dogs with side effects } & \multicolumn{6}{|c|}{ Dogs without side effects } \\
\hline Case & ALP & ALT & BUN & CHOL & Glu & Case & ALP & ALT & BUN & $\mathrm{CHOL}$ & Glu \\
\hline 1 & 2291 & 412 & 5.5 & 491.9 & 120.0 & 1 & 51 & 15 & 11.3 & 229.5 & 115.4 \\
\hline 2 & 368 & 420 & 3.4 & 288.5 & 129.1 & 2 & 96 & 96 & 22.9 & 184.9 & 121.9 \\
\hline 3 & 294 & 16 & 8.3 & 171.0 & 115.0 & 3 & 91 & 22 & 8.8 & 153.1 & 118.9 \\
\hline 4 & 93 & 106 & 5.6 & 100.3 & 105.6 & 4 & 163 & 156 & 6.4 & 97.3 & 106.1 \\
\hline 5 & 7936 & 707 & 6.7 & 176.9 & 87.9 & 5 & 185 & 53 & 11.8 & 190.9 & 142.7 \\
\hline 6 & 416 & 157 & 16.2 & 140.8 & 104.1 & 6 & 55 & 86 & 18.2 & 128.8 & 119.0 \\
\hline 7 & 71 & 37 & 16.0 & 59.4 & 103.2 & 7 & 56 & 71 & 22.4 & 115.7 & 145.6 \\
\hline 8 & 745 & 113 & 26.0 & 161.2 & 109.3 & 8 & 81 & 159 & 29.6 & 170.5 & 94.3 \\
\hline 9 & 739 & 51 & 23.8 & 155.1 & 147.3 & 9 & 43 & 52 & 8.9 & 213.4 & 153.7 \\
\hline 10 & 1533 & 554 & 32.1 & 520.0 & 111.5 & 10 & 43 & 63 & 16.0 & 161.3 & 106.8 \\
\hline 11 & 244 & 151 & 8.7 & 185.8 & 132.9 & 11 & 108 & 48 & 18.8 & 146.0 & 105.7 \\
\hline 12 & 1581 & 65 & 14.3 & 150.2 & 125.6 & 12 & 63 & 44 & 16.9 & 102.2 & 109.4 \\
\hline 13 & 96 & 32 & 6.0 & 202.0 & 94.0 & 13 & 36 & 79 & 15.7 & 168.9 & 80.6 \\
\hline 14 & 3130 & 707 & 4.6 & 140.5 & 123.7 & & & & & & \\
\hline 15 & 3130 & 500 & 6.3 & 143.2 & 135.5 & & & & & & \\
\hline 16 & 4796 & 646 & 20.5 & 450.0 & 95.0 & & & & & & \\
\hline 17 & 79 & 28 & 10.0 & 289.0 & 95.0 & & & & & & \\
\hline 18 & 2000 & 909 & 7.7 & 298.3 & 109.6 & & & & & & \\
\hline 19 & 281 & 110 & 20.4 & 93.4 & 143.1 & & & & & & \\
\hline 20 & 232 & 11 & 14.8 & 217.4 & 117.8 & & & & & & \\
\hline 21 & 176 & 42 & 13.0 & 203.7 & 119.1 & & & & & & \\
\hline 22 & 56 & 44 & 17.5 & 152.9 & 102.4 & & & & & & \\
\hline 23 & 389 & 185 & 11.0 & 321.0 & 108.0 & & & & & & \\
\hline 24 & 488 & 147 & 22.0 & 182.0 & 109.0 & & & & & & \\
\hline 25 & 1811 & 52 & 16.6 & 189.0 & 96.3 & & & & & & \\
\hline 26 & 2417 & 74 & 9.3 & 182.0 & 119.0 & & & & & & \\
\hline 27 & 77.4 & 77.6 & 16.3 & 224.7 & 110.3 & & & & & & \\
\hline
\end{tabular}

*ALP: alkaline phosphatase (U/L), ALT: alanine aminotransferase (U/L), BUN: blood urea nitrogen (mg/dl), CHOL: cholesterole (mg/dl), Glu: glucose (mg/dl).

た後，副腎機能不全による虚脱などを通常認めない。 もちろんステロイド治療により副腎予備能が完全に欠 落している症例もあり，その場合には急激な休薬によ る副腎クリーゼを懸念する必要がある。以上より，医 原性クッシング症候群の評価を ACTH-ST 単独で行う ことはできず，ACTH-ST の臨床的意義は医原性クッ シング症候群に打けるステロイド漸減スケジュールの 指標にあると考えられた。

ステロイド長期投与における血液学的異常として, グルココルチコイドの有糸分裂抑制によるリンパ球の 減少が知られており, Huang et al.は医原性クッシング 症候群の $25 \%$ で生じると報告している ${ }^{4,5)}$ 。自験例では 発症犬の半数以上に認められ, 非発症犬でも $38.5 \%$ に
生じていたことから，外因性グルココルチコイドの影 響を反映する項目であると予想された。また好酸球減 少も，本剤による異常值として強調されることがあ る。医原性クッシング症候群の $64 \%$ にみられたとの報 告もあるが5)，自験例では発症犬に多くみられるも 29.2\%にすぎなかった。血液検査は検査手技による差 異が生じやすく, ステロイド投与以外にも多因性に変 化することから，好酸球減少は医原性クッシングを評 価する方法として特異性にそしいとする記載を支持し たい。

一方血液化学検査では, ALPがクッシング症候群の 特徵的な所見であることが指摘されており，ステロイ ド投与時に扔けるモニターの1つとして注目されてい 
Table 3. Result of ACTH-ST* in dogs on glucocorticoid therapy

\begin{tabular}{|c|c|c|c|c|c|}
\hline \multicolumn{3}{|c|}{ Dogs with side effects } & \multicolumn{3}{|c|}{ Dogs without side effects } \\
\hline Case & pre & post & Case & pre & post \\
\hline 1 & 0.2 & 0.3 & 1 & 0.1 & 0.1 \\
\hline 2 & 0.2 & 3.3 & 2 & $<1.0$ & $<1.0$ \\
\hline 3 & 1.0 & 9.9 & 3 & 0.5 & 2.9 \\
\hline 4 & 0.1 & 0.3 & 4 & 0.4 & 3.9 \\
\hline 5 & 0.1 & 0.8 & 5 & 1.6 & 5.6 \\
\hline 6 & 0.2 & 0.8 & 6 & 2.5 & 7.1 \\
\hline 7 & 0.8 & 2.5 & 7 & 2.5 & 7.7 \\
\hline 8 & 1.2 & 3.5 & 8 & 0.5 & 3.3 \\
\hline 9 & 3.0 & 8.7 & 9 & $<1.0$ & 5.1 \\
\hline 10 & 0.1 & 1.2 & 10 & $<1.0$ & 9.6 \\
\hline 11 & 2.2 & 2.9 & 11 & $<1.0$ & 1.6 \\
\hline 12 & 0.8 & 0.3 & 12 & $<1.0$ & 7.0 \\
\hline 13 & 1.2 & 1.3 & 13 & 0.5 & 4.9 \\
\hline 14 & 1.4 & 3.3 & & & \\
\hline 15 & 1.7 & 4.0 & & & \\
\hline 16 & 0.2 & 0.7 & & & \\
\hline 17 & 0.1 & 0.8 & & & \\
\hline 18 & 0.1 & 5.4 & & & \\
\hline 19 & 0.9 & 10.3 & & & \\
\hline 20 & 0.1 & 0.1 & & & \\
\hline 21 & 1.6 & 2.6 & & & \\
\hline 22 & 3.1 & 8.7 & & & \\
\hline 23 & 0.1 & 0.1 & & & \\
\hline 24 & 1.3 & 4.1 & & & \\
\hline 25 & 2.3 & 4.3 & & & \\
\hline 26 & 2.8 & 8.6 & & & \\
\hline 27 & 4.0 & 15.9 & & & \\
\hline
\end{tabular}

*Plasma Coltisol revel $(\mu \mathrm{g} / \mathrm{dl})$.

る ${ }^{4,6,7)}$ 。自験例でもステロイドによる症状の発現を最 もよく反映していたのはALPの増加であり, 発症犬の $74.1 \%$ にられ，非発症犬には全く認められなかった。 ステロイドによるALPの増加は，高グルココルチコイ ド血症に起因するステロイド誘導性アイソザイムの産 生え進により生じる ${ }^{6)}$ 。ステロイド投与による副作用 の発現は個体差があると指摘されているが, ALPはス テロイド投与による血中グルココルチコイド濃度，す
なわちステロイドに対する感受性の指標となり得ると 考えられた。ALT増加も発症犬の半数以上でみられ， 非発症犬との差が顕著であった。他の検査項目はいず れの群でも異常值の発現はわずかであった。

皮膚科臨床では, ステロイドによる原因療法および 対症療法が汎用され，時に長期投与による管理が必要 であるが，その際モニターを ACTH-ST 単独で行うこ とはできず詳細な症状の観察とともにALP, ALTの測 定が不可欠であると考えられた。

本報告の要旨は, 第6回日本獣医皮膚科学会学術大 会で発表した。

\section{引用文献}

1. Behrend, E.N. and Kemppainen, R.J. 1997. Glucocorticoid therapy. Pharmacology, indications, and complications. Vet. Clin. North. Am. Small. Anim. Pract. 27: 187-213.

2. Chastain, C.B. and Graham, C.L. 1979. Adrenocortical suppression in dogs on daily and alternate-day prednisone administration. Am. J. Vet. Res. 40: 936-941.

3. Feldman, E.C. and Nelson, R.W. 1996. Canine Cushing's syndrome. pp. 187-255. In: Canine and Feline Endocrinology and Reproduction, 2nd ed, W. B. Saunders, Philadelphia.

4. Feldman, E.C. and Nelson, R.W. 1996. Glucocorticoid therapy. pp. 323-337. In: Canine and Feline Endocrinology and Reproduction, 2nd ed, W.B. Saunders, Philadelphia.

5. Huang, H-P., Yang, H-L., Liang, S-L., Lien, Y-H. and Chen, K-Y. 1999. Iatrogenic hyperadrenocorticism in 28 dogs. J. Am. Anim. Hosp. Assoc. 35: 200-207.

6. Scott, D.W., Miller, W.H. and Griffin, C.E. 2001. Canine hyperadrenocorticism. pp. 798-815. In: Small Animal Dermatology, 6th ed, W.B. Saunders, Philadelphia.

7. Solter, P.F., Hoffmann, E.E., Hungerford, L.L., Peterson, M.E. and Dorner, J.L. 1993. Assessment of corticosteroidinduced alkaline phosphatase isoenzyme as a screening test for hyperadrenocorticism in dogs. J. Am. Vet. Med. Assoc. 203: 534-538.

8. Kaneko, J.J. pp. 16. 1986. 鷲巣 月美訳. 臨床家のた めの犬猫の血液学. JSAVA, 東京. 


\title{
Relationship between Side Effects and Clinicopathological Findings in Dogs Referred to Dermatology Clinic with Long-term Glucocorticoid Administration
}

Kumiko Shibata* and Masahiko Nagata

Animal Dermatology Center, ASC

\begin{abstract}
Forty dogs reffered to our dermatology clinic with long-term glucocorticoid administration were investigated. Twenty-seven dogs showed side effects such as polyuria and polydipsia, polyphagia, abdominal enlargement, panting, muscular atrophy, alopecia, prominent vasculature, calcinosis cutis, comedo, thin skin, and/or purpura. The most significant clinicopathological abnormality related with side effects were elevations of ALP and ALT. Elevations of ALP and ALT were in $74.1 \%$ and $55.6 \%$ respectively, in dogs with side effects, against $0.0 \%$ and $15.4 \%$ respectively in dogs without side effects. In ACTH stimulation test, both dogs with and without side effects showed a high incidence of adrenal suppression, $77.8 \%$ in dogs with side effects and $69.2 \%$ in dogs without them. Based on these findings, iatrogenic Cushing's syndrome should be evaluated in dogs treated with long-term glucocorticoid administration with both clinical findings, ALP and ALT, rather than with not only ACTH stimulation test.
\end{abstract}

(Jpn J Vet Dermatol 2004, 10 (2): 41-46)

Key words: ACTH stimulation test, ALP, ALT, glucocorticoid therapy

\footnotetext{
*Correspondence to: Kumiko Shibata (Animal Dermatology Center, ASC) 1-3-2 Jindaiji-higashi, Chofu, Tokyo182-0012, Japan E-mail: shibata@gc4.so-net.ne.jp
} 